\title{
Composition of the Volatile Oils of Anthemis coelopoda var. coelopoda from Turkey
}

\section{Türkiye'den Anthemis coelopoda var. coelopoda'nın Uçucu Yağ}

\section{Bileşimi}

\author{
Research Article
}

\section{Gülden Doğan*, Azize Demirpolat and Eyüp Bağcı}

Firat University, Science Faculty, Biology Department, Elazıg, Turkey.

\section{A B S TR AC T}

\begin{abstract}
n this study, hydro distilled essential oils derived from the aerial parts of Anthemis coelopoda var. coelopoda (Asteraceae) grown in Turkey were analysed by GC and GC-MS system. Fifty seven components were identified representing $90.7 \%$ of the oils. It was determined that Anthemis coelopoda var. coelopoda essential oil contained $\beta$-caryophyllene (21.8\%), nerolidol (10.8\%), azulene (9.5\%), borneol (5.5\%), linalool (4.3\%) and cyclopentadecane (4.2\%) as major compounds. Essential oil analysis of the Anthemis coelopoda var. coelopoda has shown that it has $\beta$-caryophyllene/nerolidol and azulene chemotype.
\end{abstract}

\section{Key Words}

Anthemis, essential oil, $\beta$-Caryophyllene, nerolidol, azulene.

\section{ÖZET}

u çalışmada Türkiye'de yetişen Anthemis coelopoda var. coelopoda türünün su damıtma yöntemi ile toprak üstü kısımlarından elde edilen uçucu yağları GC ve GC-MS'de analiz edilmiştir. Toplam yağın \%90.7'sinde 57 bileşen belirlenmiştir. Anthemis coelopoda var. coelopoda'nın uçucu yağının içerdiği bu bileşenlerden $\beta$-karyofillen (\%21.8), nerolidol (10.8\%), azulen (\%9.5), borneol (\%5.5), linalool (\%4.3) ve siklopentadekan (\%4.2) büyük bileşenlerdir. Uçucu yağ çalışmaları Anthemis coelopoda var. coelopoda için $\beta$-karyofillen/ nerolidol ve azulen kemotip olduğunu göstermiştir.

\section{Anahtar Kelimeler}

Anthemis, uçucu yağ, $\beta$-karyofillen, nerolidol, azulen.

Article History: Received: Oct 05, 2015; Revised: Nov 19, 2015; Accepted: Nov 22, 2015; Available Online: Dec $30,2015$.

DOI: $10.15671 /$ HJBC.20154315983

Correspondence to: G. Doğan, Firat University, Science Faculty, Biology Department, Elazig, Turkey. 


\section{INTRODUCTION}

$\triangle$ nthemis L. is the second largest genus in Compositae, tribe Anthemideae. With its more than 210 species [1] it is outnumbered only by Artemisia L. which contains more than 500 species when Seriphidium (Besser) Fourr. is included [2,3]. The total geographical range of Anthemis encompasses most of western Eurasia, the Mediterranean region, and a small part of eastern Africa. While central Europe is inhabited by a few archaeophytic species, the main centre of diversity is found in southwestern Asia where 150 of 210 species occur, including all of the presently accepted subgenera and sections. The position of the genus within the tribe Anthemideae is still unresolved and infrageneric taxonomy of Anthemis, mainly based on life form, achene morphology, and achene anatomy, is in need of revision. According to some authors, the subgenus Cota should be treated as an independent genus [4].

Genus Anthemis (family Asteraceae, tribe Anthemideae) comprises of 62 species in Europe, which are divided into three subgenera according to the botanical classification [5]. Subgenus Anthemis includes four sections Hiorthia, Anthemis, Maruta and Chia [6]. The genus Anthemis L. is divided into three subgenera (Anthemis, Maruta, and Cota) according to the Flora of Turkey. In Turkey 81 taxa belonging to 51 species, 29 of which are endemic (54\%). These plants prefer dry, open sites on wood-steppe hillsides and grow especially on calcareous soils [7].

All of these Anthemis species are called as "Papatya" in Turkey, and this plants extensively used in Turkish folk medicine for the treatment of gastrointestinal disorders, hemorrhoid, stomach ache and kidney stones [8-13]. Papatya is a common name given to plants whose flowers resemble those of Roman and German chamomile. Many Anthemis spp. are used as herbal tea and for food flavoring, as well as cosmetics and in the pharmaceutical industry [14].

The species of the Anthemis genus are widely used in the pharmaceutics, cosmetics and food industry. The flowers of the genus have well-documented use as antiseptic and healing herbs, the main components being natural flavonoids and essential oils [15]. In Europe extracts, tinctures, tisanes (teas), and salves are widely used as anti-inflammatory, antibacterial, antispasmodic, and sedative agents. Extracts are used to allay pain and irritation, clean wounds and ulcers, and aid prevention as well as therapy of irradiated skin injuries, treatment of cystitis and dental afflic- tions [16]. The antimicrobial activity of the essential oils and different extracts from several Anthemis species has been reported before [17-19]. The occurrence of sesquiterpene lactones, flavonoids, and essential oils in various Anthemis species has been reported in previous works [14]. Sesquiterpene lactones have received considerable attention because of their chemoecological functions [20,21], biological activities, and taxonomic significance [22,23]. They represent one of the major classes of secondary metabolites in the genus Anthemis. Three skeletal types of sesquiterpene lactones-guaianolides, germacranolides, and eudesmanolides have been detected in Anthemis species [24].

Anthemis coelopoda Boiss. is erect, sparsely pubescent and annual. Stems much branched, 20-25 cm. This species flowering at $5^{\text {th }}$ and $7^{\text {th }}$ months. Anthemis coelopoda has three varieties in Turkey (var. coelopoda, var. longiloba and var. bourgaei) [7].

The aim of the present study was to perform a detailed chemical composition of the essential oil hydrodistilled from the aerial parts of Anthemis coelopoda var. coelopoda from the eastern Anatolian region in Turkey. The obteined results could be use in the clarification of infrageneric taxonomy of the genus Anthemis.

\section{MATERIALS AND METHODS}

\section{Plant Source}

Anthemis coelopoda var. coelopoda specimen was collected from natural localities (Bingol/Karlıova) in Turkey. The plant materials were collected with scissors, placed in plastic bags and transported to the laboratory. Voucher specimen was deposited in the Herbarium of the Fırat University of Elazıg (FUH) under registration number 7652 . 


\section{Extraction of the essential oil}

The essential oil was extracted by hydrodistillation using a modified Clevenger apparatus coupled to a $2 \mathrm{~L}$ round-bottom flask. A total of $100 \mathrm{~g}$ of fresh plant material (aerial parts) and $1 \mathrm{~L}$ of water were used for the extraction. The extraction was performed over 3 hour period. Subsequently, the hydrolate was collected and centrifuged at $10.000 \mathrm{rpm}$ for 10 minutes. The organic phase was removed with the aid of a Pasteur pipette, and subsequently transferred to an black coloured vials, wrapped in parafilm and aluminum foil and $4^{\circ} \mathrm{C}$ under refrigeration until analysis. The yields of oils were calculated on the basis of the dry mass.

\section{Gas chromatography (GC) analysis}

The essential oil was analysed using HP 6890 GC equipped with FID detector and HP-5 MS (30 m x $0.25 \mathrm{~mm}$ i.d., film thickness $0.25 \mu \mathrm{m}$ ) capillary column was used. The column and analysis conditions were the same as in GC-MS expressed as below. The percentage composition of the essential oils was computed from GC-FID peak areas without correction factors.

\section{Gas chromatography/Mass spectrometry (GC- MS) analysis}

GC-MS analyses of the oils were performed on a Hewlett Packard Gas Chromatography HP 6890 interfaced with Hewlett Packard 5973 mass spectrometer system equipped with a HP 5-MS capillary column $(30 \mathrm{~m} \times 0.25 \mathrm{~mm}$ id, film thickness $0.25 \mu \mathrm{m}$ ). The oven temperature was programmed from $70-240^{\circ} \mathrm{C}$ at the rate of $5^{\circ} \mathrm{C} /$ min. The ion source was set at $240^{\circ} \mathrm{C}$ and electron ionization at $70 \mathrm{eV}$. Helium was used as the carrier gas at a flow rate of $1 \mathrm{~mL} / \mathrm{min}$. Scanning range was 35 to $425 \mathrm{amu}$. Diluted oil in $\mathrm{n}$-hexane (1.0 $\mu \mathrm{L}$ ) was injected into the GC-MS.

The identification of constituents was performed on the basis of retention indices (RI) determined by co-injection with reference to a homologous series of n-alkanes, under identical experimental conditions. Further identification was performed by comparison of their mass spectra with those from NIST 98 Libraries (on ChemStation HP) and Wiley 7th Version. The relative amounts of individual components were calculated based on the GC (HP-5MS column) peak area (FID response) without using correction factors. The identified constituents of the essential oils are listed in Table 1.

\section{RESULTS AND DISCUSSION}

In this study, the chemical composition of the essential oils of dried aerial parts of Anthemis coelopoda var. coelopoda was analysed by GC and GC-MS. Fifty seven components representing $90.7 \%$ of the oils were characterized. The yields of essential oils from the sample was $0.4(\mathrm{v} / \mathrm{w})$. According to our results, the main compounds of $A$. coelopoda var. coelopoda were $\beta$-caryophyllene (21.8\%), nerolidol (10.8\%), azulene $(9.5 \%)$, borneol (5.5\%), linalool (4.3\%) and cyclopentadecane (4.2\%). The compositions of the essential oils are in Table 1.

$\beta$-caryophyllene was found as the major compound in the essential oil of $A$. coelopoda var. coelopoda. Furthermore $\beta$-caryophyllene has been detected as the main compound in the essential oil of aerial parts of $A$. cretica subsp. pontica from Turkey (20.26\%) [26], A. dipsacea from Turkey (5.6\%) [14], flower and leaves of Anthemis altissima from Iran $(25.3 \%$ and $17.2 \%$ respectively) [25]. On the other hand, $\beta$-caryophyllene has not been reported for the essential oils of $A$. pseudocotula from Turkey [26], A. tinctoria from Slovak Republic (Holla et al., 2000), Anthemis melampodina from Lübnan [18], A. xylopoda from Turkey [19], A. coelopoda var. bourgaei and A. aciphylla var. aciphylla from Turkey [13]

Azulene was reported the major compound in chemical constituents of the oils of $A$. cretica subsp. pontica from Turkey (14.98\%) [26] and in our study with $A$. coelopoda var. coelopoda (9.5\%) (Table 1), but it was not determined in the essential oils of $A$. pseudocotula [26], A. tinctoria [17], A. altissima [27], A. hyalina [28], A. xylopoda [19], A. coelopoda var. bourgaei and A. aciphylla var. aciphylla [13], A. dipsacea, A. pectinata var. pectinata and $A$. pseudocotula samples are noteworthy [14].

According to Bagher et al. (2008), cischrysanthenyl acetate (27.3\%), hexyl butanoate 
Table 1. The Composition of the Essential Oils of Anthemis coelopoda var. coelopoda.

\begin{tabular}{|c|c|c|c|}
\hline No & Compounds & $\mathbf{R} \mathbf{I}$ & $\begin{array}{c}\text { A. coelopoda var. } \\
\text { coelopoda }\end{array}$ \\
\hline 1. & $\alpha$-Pinene & 1021 & 0.4 \\
\hline 2. & Sabinene & 1052 & 0.1 \\
\hline 3. & $\beta$-Pinene & 1056 & 0.1 \\
\hline 4. & $\beta$-Myrcene & 1064 & 0.1 \\
\hline 5. & Octanol & 1067 & 0.1 \\
\hline 6. & Artemisia triene & 1069 & 0.1 \\
\hline 7. & dl-Limonene & 1095 & 0.3 \\
\hline 8. & Eucalyptol & 1098 & 0.9 \\
\hline 9. & 1,3,6-Octatriene & 1100 & 0.7 \\
\hline 10. & 1,5-Heptadien-4-one & 1117 & 0.1 \\
\hline 11. & Linalool & 1148 & 4.3 \\
\hline 12. & $2 \mathrm{H}$-Pyran-3(4H)-one & 1151 & 0.5 \\
\hline 13. & Chrysanthenone & 1164 & 0.1 \\
\hline 14. & Camphor & 1183 & 3.7 \\
\hline 15. & Borneol & 1200 & 5.5 \\
\hline 16. & 3-Cyclohexen-1-ol & 1206 & 0.4 \\
\hline 17. & Camphene & 1215 & 1.2 \\
\hline 18. & Benzocyloheptatriene & 1306 & 0.1 \\
\hline 19. & 2,4-Decadienal & 1313 & 0.1 \\
\hline 20. & Decanoic acid & 1354 & 0.2 \\
\hline 21. & $\alpha$-Copaene & 1360 & 0.1 \\
\hline 22. & $\beta$-Bourbonene & 1366 & 0.3 \\
\hline 23. & $\beta$-Elemene & 1370 & 0.7 \\
\hline 24. & $\beta$-Caryophyllene & 1394 & 21.8 \\
\hline 25. & $\beta$-Cubebene & 1400 & 0.1 \\
\hline 26. & 5,9-Undecadien-2-one & 1412 & 0.1 \\
\hline 27. & Trans- $\beta$-Farnesene & 1415 & 1.5 \\
\hline 28. & $\alpha$-Humulene & 1418 & 2.3 \\
\hline 29. & Aromadendrene & 1421 & 0.1 \\
\hline 30. & Trans- $\beta$-Ianone & 1433 & 0.1 \\
\hline 31. & Germacren D & 1435 & 2.7 \\
\hline 32. & Eudesma-4(14),11-diene & 1441 & 0.6 \\
\hline 33. & Germacren B & 1445 & 0.9 \\
\hline 34. & Germacren A & 1452 & 0.1 \\
\hline 35. & $\alpha$-Amorphene & 1456 & 0.3 \\
\hline
\end{tabular}


Table 1. The Composition of the Essential Oils of Anthemis coelopoda var. coelopoda. (continue)

\begin{tabular}{|c|c|c|c|}
\hline 36. & $\delta$-Cadinene & 1458 & 0.3 \\
\hline 37. & Napfthalene & 1479 & 0.3 \\
\hline 38. & 1,4-dimethyl-azulene & 1481 & 1.3 \\
\hline 39. & Sabinene & 1483 & 0.3 \\
\hline 40. & Nerolidol & 1499 & 10.8 \\
\hline 41. & 1H-Cycloprop(e)azulene & 1504 & 1.0 \\
\hline 42. & 3-Cyclohexen-1-carboxaldehyde & 1514 & 0.8 \\
\hline 43. & Fonenol & 1521 & 0.7 \\
\hline 44. & $\alpha$-Calacorene & 1526 & 0.7 \\
\hline 45. & Bicyclo (4.4.0) dec-1-ene & 1532 & 2.0 \\
\hline 46. & $\beta$-Guaiene & 1539 & 1.5 \\
\hline 47. & $\alpha$-Selinene & 1540 & 1.0 \\
\hline 48. & p-Mentha-1,(7), 8(10)-dien-9-ol & 1547 & 0.6 \\
\hline 49. & Trans-Caryophyllene & 1566 & 0.5 \\
\hline 50. & Azulene & 1578 & 9.5 \\
\hline 51. & Cyclopentadecane & 1602 & 4.2 \\
\hline 52. & 2-Pentadecanone & 1631 & 0.1 \\
\hline 53. & 1,2-Benzenedicarboxylic acid & 1640 & 0.2 \\
\hline 54. & Hexadecanoic acid & 1693 & 3.6 \\
\hline 55. & Cembrene & 1747 & 0.2 \\
\hline 56. & Neophytadiene & 1793 & 0.1 \\
\hline 57. & Nonadecane & 1903 & 0.3 \\
\hline \multicolumn{3}{|c|}{ Total } & 90.7 \\
\hline
\end{tabular}

RI: Retention Indice.

(16\%), and myrcene $(7 \%)$, while the leaf oil contained isobornyl formate (30.6\%), trans-ethyl chrysanthemumate (15\%) and p-mentha-1,5diene-8-ol (13.7\%) showed the highest percentage in the $A$. coelopoda Boiss. flower oil from Gilan province in Rodbar [28]. This compounds (cischrysanthenyl acetate, hexyl butanoate, isobornyl formate, trans-ethyl chrysanthemumate) was not determined in the essential oils of $A$. coelopoda var. coelopoda in our study. Whereas p-mentha1,5-diene-8-ol was not detected but low amounts p-mentha-1,(7), 8(10)-dien-9-ol (0.6\%) in our study with $A$. coelopoda var. coelopoda.

The studies undertaken on $A$. tinctoria [17] showed that the main components of the oils were 1,8 -cineole $(7.9 \%), \beta$-pinene $(7.3 \%)$, decanoic acide (5.4\%) and $\beta$-pinene (4.4\%). Santolinatriene $(27.33 \%), \quad \beta$-pinene $(6.44 \%)$ and sabinene (6.09\%) have been reported major components in A. melampodina Delile [18]. Hexadecanoic acid has been detected as the main compound in the essential oil of aerial parts of $A$. dipsacea, $A$. pectinata var. pectinata and $A$. pseudocotula from Turkey (13.5\%-9.5\%$2.7 \%$, respectively) [14]. In our study; 1,8 -cineole, decanoic acide, santolinatriene and sabinene were not determeined as major constituents, whereas $\beta$-pinene and $\beta$-pinene were determeined in very low amounts in $A$. coelopoda var. coelopoda (0.4\%-0.1\%, respectively). Furthermore hexadecanoic acid (or palmitic acid) (3.6\%) one of the major compounds in our sample. 
Javidnia et al. (2004), studied essential oils of the flowers, leaves and stems of Anthemis altissima growing wild in Iran were separately obtained by hydrodistillation and analysed by GC-MS. A total of 123 components were identified in the essential oils of the investigated organs. The main components of the flower and leaf essential oils were $\beta$-caryophyllene $(25.3 \%$ and $17.2 \%)$, caryophyllene-oxide (6.5\% and $9.6 \%$ ) and spathulenol (5.4\% and $17.4 \%)$, respectively. Nonterpenic compounds were the main components of the stem oil. Palmitic acid (39.6\%) and linoleic acid $(36.2 \%)$ constituted the main compounds of the stem oil [25].

Kilic et al. reported that (2011), the essential oils of water-distilled aerial parts of Anthemis pseudocotula and Anthemis cretica subsp. pontica were analysed by GC-MS. As a result thirty-five and forty compounds were identified representing $93.1 \%$ and $89.0 \%$ of the oils, respectively. The main compounds of $A$. pseudocotula were 1,8 -cineole $(39.40 \%)$, camphor $(9.36 \%)$, artemisiaketone $(5.68 \%)$, filifolene (5.15\%), and $\alpha$-terpineol (4.69\%), whereas $\beta$-caryophyllene (20.26\%), azulene (14.98\%), spathulenol (6.03\%), and germacrene D (5.82\%) were the major constituents of $A$. cretica subsp. pontica [26]. This indicates compliance with our work. But their study demonstrates the occurrence of the 1,8-cineole chemotype of $A$. pseudocotula whereas $\beta$-caryophyllene/nerolidol and azulene chemotype of the $A$. coelopoda var. coelopoda in our study.

In another study, A. aciphylla var. aciphylla were characterized by a high percentage of irregular monoterpenes [santolinatriene (44.2\%)], followed by [methyl chavicol (4.1\%) and terpineol (3.2\%)]. Monoterpene hydrocarbons [ $\beta$-pinene (45.2\%)] and irregular monoterpenes [santolinatriene (14.8\%)] were found to be the main components in the essential oil from the overground parts of $A$. coelopoda var. bourgaei [13].

According to Uzel et al. (2004) [19], borneol (31.8\% - 30.15\%) was among the main compounds of the flowers and leaves of $A$. xylopoda, respectively; according to Albay et al. (2009)
[29], borneol (10.6\%) also was among the main components of $A$. cretica subsp. argaea from Turkey. Whereas borneol (5.5\%) was detected as the major constituent in our study with $A$. coelopoda var. coelopoda, this compound was not determined in the essential oils of $A$. hyalina [30] and $A$. triumfetti [31].

Saroglou et al. (2006), reported that the volatile composition of eight Anthemis species. The main constituents of the investigated populations of each taxon have been revealed as follows: $A$. altissima: linalool, transcaryophyllene, cis-chrysanthenyl acetate; $A$. auriculata: spathulenol, trans-caryophyllene, $\beta$-eudesmol; $A$. chia: cis-chrysanthenyl acetate, trans-caryophyllene, germacrene-D; A. cotula: germacrene-D, spathulenol; $A$. tinctoria: spathulenol, caryophyllene oxide, t-cadinol; $A$. melanolepis: p-cymene, chrysanthenone, transverbenol, caryophyllene oxide; $A$. tomentosa: linalool, 1,8-cineole; $A$. werneri subsp. werneri: nopol, terpineol-4, trans-caryophyllene. Sesquiterpene hydrocarbons were shown to be the main group of constituents of all taxa [32]. In our study determeined as high percantage of sesquiterpene hydrocarbons of $A$. coelopoda var. coelopodA.

This study demonstrates the occurrence of $\beta$-caryophyllene/nerolidol and azulene chemotype of the Anthemis coelopoda var. coelopoda in the eastern Anatolian region of Turkey.

\section{References}

1. K. Bremer, C.J. Humphries, Generic monograph of the Asteraceae-Anthemideae. Bull. Brit. Mus. (Nat. Hist.) Bot., 23 (1993) 71-177.

2. A.B. Kornkven, L. E. Watson, J.R. Estes, Phylogenetic analysis of Artemisia section Tridentatae (Asteraceae) based on sequences from the internal transcribed spacers (ITS) of nuclear ribosomal DNA. Am. J. Bot., 85 (1998) 1787-1795.

3. M. Torrell, N. Garcia-Jacas, A. Susanna, J. Valles, Phylogeny in Artemisia (Asteraceae, Anthemideae) inferred from nuclear ribosomal DNA (ITS) sequences, Taxon, 48 (1999) 721-736.

4. C. Oberprieler, The systematics of Anthemis L. (Compositae, Anthemideae) in W and C North Africa, Bocconea, 9 (1998) 1-328. 
5. R.B. Ferandes, Taxonomic notes on the genus Anthemis L. [in: Heywood, V.H. (ed.), Flora europaea. Notulae systematicae and floram europaeam spectantes, No. 16, Bot. J. Linn. Soc., 70 (1975) 6-17.

6. J. Staneva, M. Todorova, L. Evstatieva, Sesquiterpene lactones as chemotaxonomic markers in genus Anthemis, Phytochemistry, 69 (2008) 607.

7. P.H. Davis, Flora of Turkey and the East Aegean Island, Vol. 5, Edinburgh University Press, 1975.

8. T. Baytop, Therapy with Medicinal Plants in Turkey (Past and Present). İstanbul University Publications No: 3255, Nobel Press, İstanbul, 1999.

9. G. Honda, E. Yeşilada, M. Tabata, M. Sezik, T. Fujita, Y.Takeda, Y. Takaishi, T. Tanaka, Traditional medicine in Turkey, VI. Folk medicine in West Anatolia: Afyon, Kütahya, Denizli, Muğla, Aydın provinces., J. Etnopharm., 53 (1996) 75-87.

10. R.E. Uncini Manganelli, F. Camangi, P.E. Tomei, Primi appunti su alcune tradizioni alimentari nel territorio di Massaciuccoli (LU). In: II Bacino del Massaciuccoli. V. Pacini Editore, Pisa, (1999) 49-53.

11. G. Gürhan and N. Ezer, Halk arasında hemoroit tedavisinde kullanılan bitkiler-I. Hacettepe Üniversitesi, Eczacılık Fakültesi Dergisi, 24 (2004) 37-55.

12. E. Ugurlu and O. Secmen, Medicinal plants popularly used in the villages of Yunt Mountain (Manisa-Turkey), Fitoterapia, 79 (2008) 126-131.

13. T. Gonenc, C. Argyropoulou, T. Erdogan, C. Gousiadou, G. Juergenliemk, B. Kıvçak, H. Skalts, Chemical constituents from Anthemis wiedemanniana Fisch. \& Mey., Biochemical Systematics and Ecology, 39 (2011), 51-55.

14. A. Kurtulmus, T. Fafal, T. Mert, H. Saglam, B. Kivcak, T. Ozturk, B. Demirci, K.H.C. Baser, Chemical composition and antimicrobial activity of the essential oils of three Anthemis species from Turkey, Chemistry of Natural Compounds, 45 (2009) 6.

15. S. Vaverkova, M. Haban, K. Eerna, Qualitative properties of Anthemis tinctoria and Anthemis nobilis (Chamaemelum nobile) under different environmental conditions, Ecophysiology of plant production processes in stress conditions, Abstracts of the fourth International Conference, Rackova dolina, Slovakia, 2 (2001) 1-2.

16. C. Mann, E.J. Staba, The chemistry, pharmacology, and commercial formulations of chamomile. In: Craker L.E., Simon J.E. (Eds.), Herbs, Spices, and Medicinal Plants: Recent Advances in Botany, Horticulture, and Pharmacology, vol.1. Oryx Press, Phoenix, AZ, (1986) 235-280.

17. M. Holla, E. Svajdlenka, S. Vaverkova, B. Zibrunova, J. Tekel, E. Havranek, Composition of the oil from the flowerheads of Anthemis tinctoria L. cultivated in Slovak Republic, Journal of Essential Oil Research, 12 (2000) 714-716.
18. M.H. Grace, Chemical composition and biological activity of the volatiles of Anthemis melampodina and Pluchea dioscoridis, Phytoterapy Research, 16 (2002) 183-185.

19. A. Uzel, A. Guvensen, E. Cetin, Chemical composition and antimicrobial activity of the essential oils of Anthemis xylopoda O. Schwarz from Turkey, J. Ethnopharmacol, 95 (2004) 151.

20. J. Cis, G. Nowak, W. Kisiel, Antifeedant properties and chemotaxonomic implications of sesquiterpene lactones and syringin from Phaponticum pulchrum, Biochem. Syst. Ecol., 34 (2006) 862-867.

21. J. Nawrot, Z. Smitalova, M. Holub, Deterrent activity of sesquiterpene lactones from the Umbelliferae against storage pests, Biochem. Syst. Ecol., 11 (1983) 243-245.

22. A.K. Picman, Biological activities of sesquiterpene lactones, Biochem. Syst. Ecol., 14 (1986) 255-281.

23. A.M. Zaghloul, H. Abd El-Fattah, A.F. Halim, Chemical investigation of the aerial parts of Anthemis melampodina Mansoura, J. Pharm., Sci., 5 (1989) 23-33.

24. F.C. Seaman, Sesquiterpene lactones as taxonomic characters in the Asteraceae. In: Cronquist, A. (Ed.), The Botanical Review, The New York Botanical Garden, New York, 48 (1982) 143-184.

25. K.R. Javidnia, M.. Miri, H. Kamalinejad, A. Sarkarzadeh, A. Jamalian, Chemical composition of the essential oils of Anthemis altissima L. grown in Iran, Flavour and Fragrance J., 9 (2004) 213-216,

26. O. Kilic, A. Kocak, E. Bagci, Composition of the volatile oils of two Anthemis L. Taxa from Turkey Z. Naturforsch. 66 (2011) 535-540.

27. M. Rezaee, K. Jaimand, M. Assareh, Chemical constituents of the leaf and flower oils from Anthemis altissima L. from Iran, J. Essent. Oil Res., 18 (2006) 152-165.

28. S. Sajjadi, I. Mehregan, Volatile constituents of flowers and leaves of Anthemis hyalina, Chem. Nat. Comp., 42 (2006) 531-533.

29. R.M. Bagher, K. Jaymand, V.A. Mozafarıan, Essentıal Oil Composition Of Anthemis coelopoda Boiss, Iranian Journal Of Medicinal And Aromatic Plants Fall, 24 (2008) 277-271.

30. C.G.Albay, M. Albay, N. Yayli, N. Yildirim, Essential oil analysis and antimicrobial activities of $A$. marschalliana ssp. pectinata and $A$. cretica ssp. argaea from Turkey, Asian J. Chem., 21 (2009) 14251431.

31. M. Pavlovic, N. Kovacevic, O. Tzakou, M. Couladis, Essential oil composition of Anthemis triumfetti (L.) DC. Flavour Fragr. J., 21 (2006) 297-299.

32. V. Saroglou, N. Dorizas, Z. Kypriotakis, H.D. Skaltsa, Analysis of the essential oil composition of eight Anthemis species from Greece, J. Chromatogr. A, 1104 (2006) 313-322. 
